\title{
The economic impact of compassionate use of medicines
}

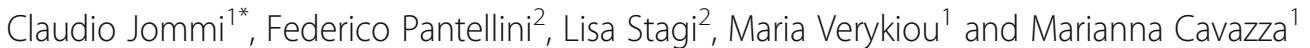

\begin{abstract}
Background: Compassionate use programs (CUP) for medicines respond to the ethical imperative of providing access to medicines before marketing approval to patients not recruited in trials. The economic impact of clinical trials has previously been investigated. No evidence on the net economic benefit of CUP exists. This research aims to address this information gap by estimating the economic consequences of 11 CUP in Italy conducted between March 2015 and December 2020 from the perspective of public health care system in Italy (National Health Service). Eight programs concern cancer treatments, two refer to spinal muscular atrophy, and one is indicated for multiple sclerosis.

Methods: Since CUP medicines are covered by the industry, the net economic benefit includes: (i) avoided costs of the Standard of Care (SoC) the patients would have received had they not joined the CUP, (ii) costs not covered by the pharmaceutical industry sponsor, but instead sustained by payers, such as those associated with adverse events (only severe side effects resulting in hospitalisation and attributable to CUP medicines), and (iii) costs for combination therapies and diagnostic procedures not used with the SoC. The SoC costing relied on publicly available data. Information on adverse events and diagnostic procedures was retrieved from the CUP and monetized using the relevant fee for episode or service. One CUP was excluded since a SoC was not identified.

Results: 2,713 patients were treated in the 11 CUP where a SoC was identified. The SoC mean cost per patient ranged from $€ 11,415$ to $€ 20,299$. The total cost of the SoC ranged between $€ 31.0$ and $€ 55.1$ million. The mean cost per patient covered by hospitals hosting CUP was equal to $€ 1,646$, with a total cost of $€ 4.5$ million. The net economic benefit ranged $€ 26.5$ million - $€ 50.6$ million.

Conclusions: Despite research limitations, this paper illustrates for the first time the net economic impact of CUP from a public payer perspective. It is important to integrate these estimates with the prospective effects of CUP implementation, i.e., the economic value of the comparative benefit profile of medicines used in CUP versus the SoC, including effects from a societal perspective.
\end{abstract}

Keywords: Compassionate Use, Medicines, Economic Impact, Italy

\footnotetext{
* Correspondence: claudio.jommi@unibocconi.it

${ }^{1}$ Centre for Research on Health and Social Care Management, SDA Bocconi

School of Management, CERGAS, Bocconi University, Via Sarfatti 25, 20136

Milano, MI, Italy

Full list of author information is available at the end of the article
}

(c) The Author(s). 2021 Open Access This article is licensed under a Creative Commons Attribution 4.0 International License, which permits use, sharing, adaptation, distribution and reproduction in any medium or format, as long as you give appropriate credit to the original author(s) and the source, provide a link to the Creative Commons licence, and indicate if changes were made. The images or other third party material in this article are included in the article's Creative Commons licence, unless indicated otherwise in a credit line to the material. If material is not included in the article's Creative Commons licence and your intended use is not permitted by statutory regulation or exceeds the permitted use, you will need to obtain permission directly from the copyright holder. To view a copy of this licence, visit http://creativecommons.org/licenses/by/4.0/. The Creative Commons Public Domain Dedication waiver (http://creativecommons.org/publicdomain/zero/1.0/) applies to the data made available in this article, unless otherwise stated in a credit line to the data. 


\section{Background}

Access to unauthorized treatments can be achieved through participation in clinical trials (CT) or through early access programs. The latter includes different mechanisms, and different terminologies often to the same effect, such as individual named-patient, managed access, compassionate use, early, pre-approval, or expanded access programs [1].

Compassionate Use Programs (CUP) allow for the unauthorized use of a medicine outside a CT, where the cost of treatment is borne by the pharmaceutical sponsor. While the primary objective of a CT is to generate evidence on the safety and efficacy of a treatment against an unmet need, that of a CUP is addressing an unmet medical need for ethical reasons [1]. According to the Regulation (EC) No 726/2004 of the European Parliament, a CUP allows "a group of patients with a chronically or seriously debilitating disease or whose disease is considered to be life-threatening, and who cannot be treated satisfactorily by an authorised medicinal product" to have access to a product that is the object of an application for marketing authorisation or of a CT [2, 3].

Until recently, patients in Italy with a specific disease with no treatment option could be provided access, through their physicians, to innovative drugs authorised for use in any other country, unauthorised drugs under CT, as well as drugs different from those authorised for the intended therapeutic indication (off-label) [4]. In 2017, a new decree from the Italian Ministry of Health came into effect [5] reflecting the above EU regulations, while also authorising, as previously, the use in CUP of off-label licensed products and EC-approved products not yet licensed in Italy. By way of this decree, the definition encompasses access to unauthorized medicines, on a named (individual) basis as well as in a group program through their physicians, and to patients who suffer from severe and rare diseases or life-threatening conditions. Patients should have no other valid therapeutic alternatives, or cannot be recruited in a CT or had previously participated in a CT and demonstrated positive health outcomes, and can in this way be guaranteed continuity of care outside the CT. Authorization for conducting a CUP is based on evidence from ongoing Phase III CT, Phase II for life threatening or severe diseases, and Phase I for drugs for rare diseases or rare cancers, provided that Phase I results demonstrate efficacy and safety of the medicinal product at a given dosage and schedule of administration. CUP covers drugs before marketing authorisation, but in exceptional circumstances it can be prolonged as long as they are reimbursed by the National Health Service.

The use of unapproved drugs outside of clinical trials through compassionate use is the subject of debate among scientific community from different perspectives.
Through CUP, pharmaceutical companies can respond rapidly and efficiently to the demand for an unmet need prior to authorization, thus streamlining the transition and launch of the product to market with real-world data [4]. These data may play an important role in regulatory decisions and can be incorporated in the registration and pricing of a product [4]. Provided that the treatment works, patients' health is benefited, on the other hand, by accessing a treatment earlier in the evolution of their pathology, and thus avoiding health deterioration due to long waiting times until official market authorization [6]. Evidence from the Netherlands suggests that patients who suffer from chronic or lifethreatening diseases actively seek alternative options through CUP despite their varying level of understanding and information regarding availability and access [7]. On the other hand, doctors in the Netherlands reportedly have a more critical perception of CUP, in the form of expanded access program. They quote practical hurdles related to the application process and the moral issue of providing an early access to medicines that may not be approved or approved for the indication different from the one of CUP [8]. The point has been raised that with increasing awareness of the efficacy of new drugs through internet platforms and with potential inequities in pre-approval treatment access, healthcare providers, policy makers and pharmaceutical industry should find common solutions to manage patients' expectations in a fair and ethical way [9]. Finally, CUP can bring added value to society and third-party payers in economic terms, who may benefit from avoiding part of the cost of treating a severely ill patient with the existing standard of care (SoC) -whose relative effectiveness is often questionable- by instead shifting the burden to industry, which will cover most of the investigative treatment's costs under the CUP.

Our research looked at CUP from the economic view and the perspective of the Italian public health care system. This system was shaped, since 1978, as a National Health Service (NHS) model, where the State is the most important financer, via general tax levies. A high proportion of health care expenditure is covered by the NHS (76.1\% in 2019) [10]. The pharmaceutical market is highly regulated, with price and reimbursement simultaneously negotiated by the National Medicines Agency and the pharmaceutical companies [11]. Medicines used in hospital settings are fully reimbursed by the NHS, whereas retail drugs are subject to co-payment and non-prescription medicines are not reimbursed. The NHS reimbursed $71 \%$ of total pharmaceutical expenditure in 2020 [12].

More specifically, our research questions are: what costs would have been incurred by payers for treating patients had the latter not been part of a CUP (averted costs thanks to CUP)? What are the incremental costs 
incurred by the National Health Service due to patients' inclusion in a CUP (incremental costs due to CUP)?

\section{Methods}

We firstly carried out a literature review of the evidence on the economic impact of CUP. More specifically, a non-exhaustive review was performed on PubMed and Google Scholar to identify relevant research presenting evidence on third-party payer avoided and sustained costs for treatment of patients enrolled in CUP. Keywords used in the search included: "cost avoidance" (or) "economic impact" (or) "cost saving" (or) "economic value" (and) "compassionate use" (or) "early access". As no specific papers were found on CUP, we extended the analysis to "clinical trial(s)", to scrutinise methods and findings of these studies.

The empirical analysis was carried out on a database on CUP launched by Roche in Italy from 2015 to 2020 . The CUP database includes anonymised information on patients (gender and age), compassionate use treatments (CUT), medicines used in combination (duration, dose), side effects classified according to $\operatorname{MedDRA}^{\circ}$ [13], their severity, and whether, according to the company providing the CUT and/or by the hosting healthcare centre, they were associated with the CUT. We have considered only severe adverse events associated with the CUT in the case where they resulted in hospitalization.

For the purposes of this study, averted costs are defined as the $\mathrm{SoC}$ costs that would have otherwise been covered by healthcare providers if patients had not been included in the CUP. Averted costs of the SoC were estimated in three steps:

- we identified programs where the SoC did not exist when the patient started the CUT and eliminated from the analysis;

- the SoC for all other CUT was identified on the grounds of pivotal studies for CUT (where SoC was used as an active comparator), European/National Guidelines, or Regional Documents, and was validated by clinicians;

- the mean SoC cost per patient was estimated, i.e., unit price per dose * mean number of doses. In Italy, as in many other countries, public prices do not necessarily coincide with actual prices paid by hospitals, due to hidden discounts negotiated at central and regional levels and/or the effects of financial or outcome-based managed entry agreements (MEA) [11]. In 2017, discounts and MEA accounted for $25 \%$ and $12 \%$ of public price, respectively, for all medicines procured by hospitals [14]. As this information is not publicly available for each single medicine, we relied on actual prices published in regional documents, where those were available.
Where they were not, we calculated the cost as the public price due for all non-innovative medicines, i.e., net of the compulsory discounts $(5 \%+5 \%)$ per $\mathrm{mg}$ * unit dose retrieved from Summary of Product Characteristics $(\mathrm{SmPC})$ in $\mathrm{mg}$ * median/mean treatment duration derived from SmPC or pivotal trials or other documents.

Incremental costs incurred by the CUP include:

- costs of medicines given in combination with CUT not covered by the company providing CUT for CUP;

- costs of diagnostic procedures incurred due to CUT but not covered by the company (procedure outside of normal clinical practice) which would not have been otherwise incurred with the SoC;

- costs of severe (i.e. generating hospitalisation) side effects associated with the CUT by the company providing the CUT and/or by the hosting healthcare centre.

The cost of combination therapy not covered by the company providing the CUT was calculated as the price for each patient, net of compulsory discounts $(5+5 \%)$, * unit dose from the CUP dataset * treatment duration from the CUP dataset.

In Italy, diagnostic procedures and inpatient care are reimbursed through fee-for-service and fee-for-episode schemes, respectively [15]. The fee-for-service for ambulatory care was monetized using the most updated regional fees (Lombardy and Veneto) [16, 17], because national fees have not been updated since 1996 [18]. Hospitalisation fees were retrieved from the national database and are up to date as of 2012. Hospitalisations are classified according to the DRG - DiagnosticRelated Group - system (ICD-9-CM 2007 version and Medicare DRG classification 24th version) [19]. DRG classification of inpatient episodes does not correspond with the one used by MedDRA ${ }^{\circ}$. We relied on the eDRGs platform [20] to associate the MedDRA ${ }^{\circ}$ denomination with the relevant DRG (and the corresponding fee).

\section{Results}

Literature review on economic impact of clinical trials A total of 21 studies were identified, with most evidence published for Spain and the USA (United States of America) (4 papers each), followed by Canada and Italy (3 papers each), while single publications included data for Australia, Austria, France, Germany, Taiwan, Turkey, and UK (United Kingdom).

Of these studies, one pertained to the measurement of costs of specific side-effects during CT [41], one 
Table 1 Evidence on the economic impact of Clinical Trials

\begin{tabular}{|c|c|c|c|c|c|c|c|c|c|}
\hline $\begin{array}{l}\text { Ref. } \\
\text { ID }\end{array}$ & Country & $\begin{array}{l}\text { Therapeutic } \\
\text { Area }\end{array}$ & $\begin{array}{l}\text { \# of } \\
\text { trials }\end{array}$ & Phase & $\begin{array}{l}\text { \# of } \\
\text { patients }\end{array}$ & Year(s) & $\begin{array}{l}\text { Cost items included } \\
\text { (medicines, } \\
\text { diagnostics, side } \\
\text { effects, trial } \\
\text { management, } \\
\text { others) }\end{array}$ & $\begin{array}{l}\text { Methods } \\
\text { (clinical trial } \\
\text { data / clinical } \\
\text { trial protocol / } \\
\text { mixed) }\end{array}$ & $\begin{array}{l}\text { Main findings (total cost avoided / } \\
\text { mean cost avoided per patient } \\
\text { recruited) }\end{array}$ \\
\hline$[24]$ & Australia & Haematology & 36 & I, II, III & 245 & $\begin{array}{l}2006- \\
2017\end{array}$ & Medicines & $\begin{array}{l}\text { Clinical trial } \\
\text { data }\end{array}$ & $€ 4,278,116$ total cost avoided \\
\hline$[25]$ & Austria & Multiple & 1,029 & I, II, III, IV & 23,331 & $\begin{array}{l}2012- \\
2017\end{array}$ & $\begin{array}{l}\text { Medicines, } \\
\text { diagnostics, side } \\
\text { effects, others }\end{array}$ & $\begin{array}{l}\text { Clinical trial } \\
\text { protocol }\end{array}$ & $€ 100.5 \mathrm{mi}$ saved annually \\
\hline [26] & Canada & Cancer & 21 & III & 4,674 & $\begin{array}{l}1999- \\
2011\end{array}$ & Medicines, diagnostics & $\begin{array}{l}\text { Clinical trial } \\
\text { protocol }\end{array}$ & $\begin{array}{l}\text { The total Drug Cost Avoidance } \\
\text { (DCA) was estimated at } € 20,308,422 \\
\text { of which targeted therapy } \\
\text { constituted } 43 \% \text { (five trials). The } \\
\text { combined Pathology Cost Avoidance } \\
\text { (PCA) and DCA was } € 23,356,118 \text { for a } \\
\text { cost avoidance per patient of } \\
€ 5,447.83\end{array}$ \\
\hline \multirow[t]{3}{*}{ [27] } & \multirow[t]{3}{*}{ Canada } & \multirow[t]{3}{*}{ Cancer } & \multirow[t]{3}{*}{37} & \multirow[t]{3}{*}{$|/ I I, \|| I \mid}$, & \multirow[t]{3}{*}{250} & \multirow[t]{3}{*}{$\begin{array}{l}2001- \\
2006\end{array}$} & \multirow[t]{3}{*}{ Medicines } & \multirow[t]{3}{*}{$\begin{array}{l}\text { Clinical trial } \\
\text { protocol }\end{array}$} & $\begin{array}{l}\text { Drug specific cost avoidance per } \\
\text { patient: } € 7.99 \text { - } € 169,885.51\end{array}$ \\
\hline & & & & & & & & & $\begin{array}{l}\text { Potential drug specific cost } \\
\text { avoidance per patient: } € 9.62 \text { - } \\
€ 195,000.48\end{array}$ \\
\hline & & & & & & & & & $\begin{array}{l}\text { Actual drug cost avoidances } \\
\text { according to tumour group were } \\
\text { calculated showing a median range } \\
\text { of } € 936.74 \text { - } € 16,157.14 \text { per patient } \\
\text { between tumour groups. The } \\
\text { median range for potential drug cost } \\
\text { avoidance was substantially higher } \\
\text { from } € 6,712.93 \text { - } € 31,727.89 \text { per } \\
\text { patient }\end{array}$ \\
\hline$[28]^{0}$ & Canada & Breast cancer & 8 & III & 97 & $\begin{array}{l}2006- \\
2009\end{array}$ & $\begin{array}{l}\text { Medicines, } \\
\text { diagnostics, trial } \\
\text { management, others }\end{array}$ & $\begin{array}{l}\text { Clinical trial } \\
\text { data }\end{array}$ & $\begin{array}{l}\text { Mean additional total costs between } \\
C T \text { and SoC patients of } € 4,601 \text { ( } 95 \% \\
\text { confidence interval: } € 94 \text { - } € 9,109 p= \\
0.046 \text { ) }\end{array}$ \\
\hline \multirow[t]{2}{*}{ [29] } & \multirow[t]{2}{*}{ France } & \multirow{2}{*}{$\begin{array}{l}\text { Oncology - } \\
\text { Haematology }\end{array}$} & \multirow[t]{2}{*}{27} & \multirow[t]{2}{*}{ III } & \multirow[t]{2}{*}{177} & \multirow{2}{*}{$\begin{array}{l}2011- \\
2016\end{array}$} & \multirow[t]{2}{*}{ Medicines } & \multirow[t]{2}{*}{ Mixed } & Total cost savings were $€ 5.2 \mathrm{mi}$ \\
\hline & & & & & & & & & $\begin{array}{l}\text { Mean cost saving per patient was } \\
€ 19,182.7 \pm € 29,865.7\end{array}$ \\
\hline \multirow[t]{2}{*}{ [23] } & \multirow[t]{2}{*}{ Germany } & \multirow[t]{2}{*}{ Oncology } & \multirow[t]{2}{*}{88} & \multirow{2}{*}{$\begin{array}{l}\text { Un- } \\
\text { specified }\end{array}$} & \multirow{2}{*}{$\begin{array}{l}\text { Un- } \\
\text { specified }\end{array}$} & \multirow{2}{*}{$\begin{array}{l}2002- \\
2005\end{array}$} & \multirow[t]{2}{*}{ Medicines } & \multirow[t]{2}{*}{ Mixed } & $€ 5.1 \mathrm{mi}$ potential drug cost savings \\
\hline & & & & & & & & & $€ 1.5 \mathrm{mi}$ actual drug cost savings \\
\hline [30] & Italy & Lung cancer & 12 & $\begin{array}{l}\text { Un- } \\
\text { specified }\end{array}$ & 44 & 2010 & Medicines, diagnostics & $\begin{array}{l}\text { Clinical trial } \\
\text { contract }\end{array}$ & $€ 243,154$ drug cost savings \\
\hline \multirow[t]{2}{*}{ [31] } & \multirow[t]{2}{*}{ Italy } & \multirow[t]{2}{*}{ Oncology } & \multirow[t]{2}{*}{34} & \multirow[t]{2}{*}{ I, II, III } & \multirow[t]{2}{*}{126} & \multirow[t]{2}{*}{2017} & \multirow[t]{2}{*}{ Medicines } & $\begin{array}{l}\text { Clinical trial } \\
\text { protocol }\end{array}$ & $\begin{array}{l}\text { Average hospital saving of } € 5,487 \\
\text { per patient treated in pharma } \\
\text { sponsored studies and } € 206 \text { for } \\
\text { investigator-led studies }\end{array}$ \\
\hline & & & & & & & & & $\begin{array}{l}€ 517,658 \text { in a month for drugs that } \\
\text { otherwise would have been loaded } \\
\text { on the Italian National Health Service }\end{array}$ \\
\hline [32] & Italy & Oncology - & 29 & $\|\|$, & 189 & $2011-$ & Medicines & Mixed & Total avoided costs of $€ 330,000$ \\
\hline & & & & & & & & & $\begin{array}{l}\text { Potential total avoided costs at } \\
\text { national level would range from } 320 \\
\text { to } 360 \text { million €/year }\end{array}$ \\
\hline [33] & Spain & Lung cancer & 12 & I, II, III & 69 & 2016 & Medicines & $\begin{array}{l}\text { Clinical trial } \\
\text { data }\end{array}$ & $\begin{array}{l}\text { The overall avoided cost was } \\
€ 474,428.65 \text {. The average cost per } \\
\text { clinical trial was } € 39,535.72 \text { and per } \\
\text { patient was } € 6,875.77\end{array}$ \\
\hline [34] & Spain & Prostate & 5 & III & 136 & 1996- & Medicines & Clinical trial & $€ 696,002$ total cost avoidance \\
\hline
\end{tabular}


Table 1 Evidence on the economic impact of Clinical Trials (Continued)

\begin{tabular}{|c|c|c|c|c|c|c|c|c|c|}
\hline $\begin{array}{l}\text { Ref. } \\
\text { ID }\end{array}$ & Country & $\begin{array}{l}\text { Therapeutic } \\
\text { Area }\end{array}$ & $\begin{array}{l}\text { \# of } \\
\text { trials }\end{array}$ & Phase & $\begin{array}{l}\text { \# of } \\
\text { patients }\end{array}$ & Year(s) & $\begin{array}{l}\text { Cost items included } \\
\text { (medicines, } \\
\text { diagnostics, side } \\
\text { effects, trial } \\
\text { management, } \\
\text { others) }\end{array}$ & $\begin{array}{l}\text { Methods } \\
\text { (clinical trial } \\
\text { data / clinical } \\
\text { trial protocol / } \\
\text { mixed) }\end{array}$ & $\begin{array}{l}\text { Main findings (total cost avoided / } \\
\text { mean cost avoided per patient } \\
\text { recruited) }\end{array}$ \\
\hline & & cancer & & & & 2013 & & data & $\begin{array}{l}€ 139,200 \text { average cost avoidance per } \\
\text { clinical trial }\end{array}$ \\
\hline & & & & & & & & & $\begin{array}{l}€ 5,118 \text { average cost avoidance per } \\
\text { patient }\end{array}$ \\
\hline \multirow[t]{3}{*}{ [35] } & \multirow[t]{3}{*}{ Spain } & \multirow[t]{3}{*}{ Breast cancer } & \multirow[t]{3}{*}{37} & \multirow[t]{3}{*}{ I, II, III } & \multirow[t]{3}{*}{89} & \multirow[t]{3}{*}{$\begin{array}{l}2014- \\
2016\end{array}$} & \multirow[t]{3}{*}{ Medicines } & \multirow[t]{3}{*}{$\begin{array}{l}\text { Clinical trial } \\
\text { protocol }\end{array}$} & $\begin{array}{l}80 \% \text { of cost savings were derived } \\
\text { from phase III trials }\end{array}$ \\
\hline & & & & & & & & & $€ 957,246$ total cost avoidance \\
\hline & & & & & & & & & $\begin{array}{l}€ 10,756 \text { average cost avoidance per } \\
\text { patient }\end{array}$ \\
\hline [36] & Spain & Oncology & 38 & $\begin{array}{l}\text { Un- } \\
\text { specified }\end{array}$ & 261 & $\begin{array}{l}2017- \\
2018\end{array}$ & Medicines & $\begin{array}{l}\text { Clinical trial } \\
\text { (unspecified) }\end{array}$ & $\begin{array}{l}\text { Avoided cost: } € 3,482,662 \text { / year; } \\
€ 13,343 / \text { patient }\end{array}$ \\
\hline [37] & Taiwan & Multiple & 194 & I, II, III, IV & 2,883 & 2008 & Medicines & $\begin{array}{l}\text { Clinical trial } \\
\text { data }\end{array}$ & $\begin{array}{l}\text { Average cost avoidance of } € 39,456 / \\
\text { trial-year or } € 26,531 / \text { participant-year }\end{array}$ \\
\hline [38] & Turkey & Multiple & 174 & I, II, III, IV & 1,437 & $\begin{array}{l}2006- \\
2010\end{array}$ & Medicines & $\begin{array}{l}\text { Clinical trial } \\
\text { data }\end{array}$ & $€ 212,478,657$ government saving \\
\hline [39] & UK & Oncology & 53 & $\|\| I \|$, & 357 & $\begin{array}{l}2009- \\
2010\end{array}$ & $\begin{array}{l}\text { Medicines, } \\
\text { diagnostics, trial } \\
\text { management, others }\end{array}$ & $\begin{array}{l}\text { Clinical trial } \\
\text { protocol }\end{array}$ & $\begin{array}{l}€ 436,763 \text { (2009) and €344,833 (2010) } \\
\text { overall treatment cost savings }\end{array}$ \\
\hline \multirow[t]{4}{*}[40]{$^{*}$} & \multirow[t]{4}{*}{ USA } & \multirow[t]{4}{*}{ Multiple } & \multirow[t]{4}{*}{6,199} & \multirow[t]{4}{*}{$\begin{array}{l}0, I,\|,\| I, \\
I V\end{array}$} & \multirow[t]{4}{*}{$1,100,000$} & \multirow[t]{4}{*}{2013} & \multirow[t]{4}{*}{$\begin{array}{l}\text { Medicines, } \\
\text { diagnostics, trial } \\
\text { management, others }\end{array}$} & \multirow[t]{4}{*}{$\begin{array}{l}\text { Clinical trial } \\
\text { data }\end{array}$} & $\begin{array}{l}\text { Estimates of Overall Economic } \\
\text { Impact of Industry-Sponsored Clinical } \\
\text { Trial Activities at U.S. Trial Sites } 2013\end{array}$ \\
\hline & & & & & & & & & $\begin{array}{l}\text { Direct - Research activities at clinical } \\
\text { trial sites around the country } € 7.4 \text { bn }\end{array}$ \\
\hline & & & & & & & & & $\begin{array}{l}\text { Indirect and Induced - Vendors and } \\
\text { suppliers to trial sites; Consumer } \\
\text { purchases by researchers and } \\
\text { workers engaged in or supporting } \\
\text { the clinical trial process } € 11.4 \text { bn }\end{array}$ \\
\hline & & & & & & & & & Total $€ 18.8$ bn \\
\hline \multirow[t]{2}{*}[41]{$^{\S}$} & \multirow[t]{2}{*}{ USA } & \multirow[t]{2}{*}{ Lung cancer } & \multirow[t]{2}{*}{4} & \multirow[t]{2}{*}{ III } & \multirow[t]{2}{*}{31} & \multirow[t]{2}{*}{2017} & \multirow{2}{*}{$\begin{array}{l}\text { Medicines, } \\
\text { diagnostics, trial } \\
\text { management, side } \\
\text { effects, others }\end{array}$} & \multirow[t]{2}{*}{$\begin{array}{l}\text { Clinical trial } \\
\text { data }\end{array}$} & $\begin{array}{l}\text { The mean cost to treat an event of } \\
\text { grade } 3 \text { nausea was } € 12,135\end{array}$ \\
\hline & & & & & & & & & $\begin{array}{l}\text { The mean costs to treat an event of } \\
\text { grade } 3-4 \text { thrombocytopenia } \\
\text { combined excluding and including } \\
\text { hospitalization costs were } € 544,885 \\
(\mathrm{SD}=€ 1,283.15) \text { and } € 3,678(\mathrm{SD}= \\
€ 8,418.80 \text { ) respectively }\end{array}$ \\
\hline [22] & USA & $\begin{array}{l}\text { Oncology } \\
\text { and AIDS }\end{array}$ & 255 & $\begin{array}{l}\text { Un- } \\
\text { specified }\end{array}$ & 756 & $\begin{array}{l}1996- \\
97\end{array}$ & Medicines & $\begin{array}{l}\text { Clinical trial } \\
\text { data }\end{array}$ & $€ 2.7 \mathrm{mi}$ cost avoidance in drug costs \\
\hline [21] & USA & Multiple & 107 & $\begin{array}{l}\text { Un- } \\
\text { specified }\end{array}$ & $\begin{array}{l}\text { Un- } \\
\text { specified }\end{array}$ & $\begin{array}{l}2000- \\
2002\end{array}$ & Medicines & Mixed & $\begin{array}{l}\text { Mean drug cost avoidance } \\
€ 2,417,117 \text { per year }\end{array}$ \\
\hline
\end{tabular}

${ }^{0}$ Additional costs incurred by CT versus SoC reported

*Grey literature report on cumulative economic impact of industry trials in the USA in one year

${ }^{\S}$ Side-effects costs

comprised a grey literature report on the total impact and savings incurred by CT in the USA [40], and one reported on additional costs incurred by $\mathrm{CT}$ versus $\mathrm{SoC}$ [28]. These studies were excluded from the following description of available evidence of CT avoided costs but are included as references in Table 1.
In the remaining 18 publications reporting $\mathrm{CT}$ avoided costs, the number of CT included in each paper ranged from 4 to 1,029 , with recruitment of a total of 44 to 23,331 patients. The majority $(78 \%)$ of the publications report savings on medicine costs, while the rest also reported on diagnostics, clinical trial management, side 
effects, and other cost items. Costs were converted from the reported currencies to Euros using the average exchange rate of the year of the most recent data presented in each paper. Out of the 18 studies, six used clinical trial data, six extracted data from protocols, four studies employed mixed methods (data and protocols), one extracted data from clinical trial contracts, while for one study the source of data was not available. The average cost savings on all cost items reported in the available evidence range from $€ 1,095$ to $€ 49,301$ per patient and from $€ 7,374$ to $€ 968,000$ per clinical trial. Avoided drug costs reported in studies measuring only medicine costs ranged from $€ 1,746$ to $€ 49,301$ per patient and from $€ 10,588$ to $€ 193,259$ per clinical trial. The total reported cost savings ranged from $€ 4,601$ (97 patients in CT) to $€ 212.5$ million (14,370 patients in CT). Finally, three studies $[25,32,38]$ were able to provide projected annual cost avoidance estimates on a national scale, which averaged to $€ 217.7$ million per year. As evidenced in Table 1, studies were included that reported total costs for multiple pathologies and multiple clinical trial phases. This is one of the reasons for the large range of cost avoidance found in the literature, combined with other factors such as the duration patients remain on a trial, which may vary across therapeutic areas, the number of days in each cycle a drug is administered, the number of clinic visits, and the price of the drugs.

\section{Empirical analysis}

The Database on CUP launched by Roche in Italy from 2015 to 2020 includes 11 program and 2,745 patients (53 CUP were available in Italy in October 2021) [68]. These programs concerned 8 medicines / indications for cancer (1,641 patients, $59.8 \%$ of all patients), one for primary progressive multiple sclerosis $(1,045,38.1 \%$ of patients), and two for spinal muscular atrophy (59, $2.1 \%$ of all patients) (Table 2).

Two programs were excluded from the analysis since the SoC was not available: risdiplam for Type 2 Spinal Muscular Atrophy - SMA (31 patients) and entrectinib for solid tumours expressing a neurotrophic tyrosine receptor kinase - NTRK - gene fusion (1 patient). Data were elaborated for 2,713 patients.

Input data are illustrated in Table 3: identified SoC; combination therapies - whether they are covered by the company providing the CUT or the NHS; diagnostic tests - whether they are covered by the company providing the CUT or used also with the SoC or covered by the NHS; and hospitalisations due to side effects of the CUT or the relevant combination therapy. Side effects of CUT or combination therapies resulted in hospitalisation for $2.1 \%$ of patients.

Table 4 highlights the averted mean cost per patient due to avoided treatment with the $\mathrm{SoC}$, and the mean incremental costs for hospitals due to the CUP program. The former ranges from $€ 3,002$ (rituximab for Primary Progressive Multiple Sclerosis) to $€ 200,000$ (nusinersen for Type-1 SMA). Diagnostic tests are annulled as either covered by the company or cancelled out since they would have also been used with the SoC. The three exceptions are represented by:

- IHC (Immuno-Histo-Chemistry) and follow-up bilirubin and albumin protein for alectinib for adult patients with Anaplastic Lymphoma Kinase (ALK)positive advanced Non-Small Cell Lung Cancer (NSCLC);

- Hepatitis B testing to identify patients at risk of reactivation with ocrelizumab;

- Fluorescent In-Situ Hybridization (FISH) for trastuzumab emtansine.

The mean cost per hospitalised patient due to adverse events amounts to $€ 2,184$, ranging from $€ 1,404$ to $€ 2,488$ (Table 4). As 57 out of 2,713 patients presented severe side effects resulting in hospitalisation, the mean cost of hospitalisation per patient recruited in CUP equals to $€ 45$.

The mean averted cost per patient due to avoided use of the SoC ranged from $€ 11,415$ to $€ 20,299$ and from $€ 13,555$ to $€ 28,235$ for all programs and cancer CUP, respectively. The mean incremental cost of all CUP (combination therapies, diagnostic tests, and hospitalisations due to side effects) amounted to $€ 1,646$, and to $€ 2,694$ for cancer CUP. Total savings for payers ranged from $€ 26.5$ million ( $€ 17.8$ for cancer CUP) to $€ 50.6$ million (€41.9 million for cancer CUP) (Table 5). Mean savings per patient ranged from $€ 10,861$ to $€ 25,559$.

Appendix 1 lists the averted costs, incremental costs, and net costs for each CUP. Net costs are mostly driven by the mean averted cost of the SoC, and the number of patients recruited in the CUP.

\section{Discussion}

This paper has investigated, for the first time in the literature, the economic consequences of 11 CUP for medicines from the perspective of the NHS. Avoided costs of treating patients with the SoC, if existing and reimbursed, incremental costs of diagnostics, combination therapies, and side effects of CUT were included. Savings generated by the CUP ranged from $€ 26.5$ million ( $€ 9.8 \mathrm{k}$ per patient) to $€ 50.6$ million ( $€ 18.7 \mathrm{k}$ per patient), depending on the SoC used as an alternative to the CUT.

These findings cannot be fully compared with the economic impact of a CT. If Italian studies on CT avoided costs are considered, regarding only medicines [31, 32] and diagnostic procedures [30], the mean savings per 
Table 2 Compassionate Use Programs available in the CUP Database

\begin{tabular}{|c|c|c|c|c|c|}
\hline \# of CUP & Molecule & Indication & $\begin{array}{l}\text { Indication } \\
\text { (short) }\end{array}$ & $\begin{array}{l}\text { \# of } \\
\text { patients }\end{array}$ & $\begin{array}{l}\text { Starting } \\
\text { month of } \\
\text { CUP }\end{array}$ \\
\hline MO29499 & Alectinib & $\begin{array}{l}\text { Adult patients with Anaplastic Lymphoma Kinase (ALK)-positive advanced } \\
\text { Non-Small Cell Lung Cancer (NSCLC) }\end{array}$ & $\begin{array}{l}\text { Non-Small Cell } \\
\text { Lung Cancer } 1\end{array}$ & $21^{\circ}$ & March 2015 \\
\hline ML40066 & Alectinib & $\begin{array}{l}\text { Adult patients with ALK-positive advanced NSCLC, previously treated with } \\
\text { crizotinib }\end{array}$ & $\begin{array}{l}\text { Non-Small Cell } \\
\text { Lung Cancer } 2\end{array}$ & $226^{\circ}$ & May 2017 \\
\hline ML39740 & Atezolizumab & $\begin{array}{l}\text { Adult patients with locally advanced or metastatic Urothelial Carcinoma (UC) } \\
\text { after prior platinum-containing chemotherapy, or considered cisplatin ineli- } \\
\text { gible, and whose tumours have a PD-L1 expression } \geq 5 \%\end{array}$ & $\begin{array}{l}\text { Urothelial } \\
\text { Carcinoma }\end{array}$ & $222^{\circ}$ & $\begin{array}{l}\text { February } \\
2017\end{array}$ \\
\hline AL41528 & Atezolizumab & $\begin{array}{l}\text { Adult patients with locally advanced or metastatic NSCLC after prior } \\
\text { chemotherapy (patients with EGFR mutant or ALK-positive NSCLC should also } \\
\text { have received targeted therapies before) }\end{array}$ & $\begin{array}{l}\text { Non-Small Cell } \\
\text { Lung Cancer }\end{array}$ & $125^{\circ}$ & June 2019 \\
\hline AL41712 & Atezolizumab & $\begin{array}{l}\text { Adult patients with unresectable locally advanced or metastatic Triple- } \\
\text { Negative Breast Cancer (TNBC), whose tumours have PD-L1 expression } \geq 1 \% \\
\text { and who have not received prior chemotherapy for metastatic disease }\end{array}$ & $\begin{array}{l}\text { Triple-Negative } \\
\text { Breast Cancer }\end{array}$ & $41^{\circ}$ & $\begin{array}{l}\text { November } \\
2019\end{array}$ \\
\hline M029476 & Cobimetinib & $\begin{array}{l}\text { Adult patients with unresectable or metastatic Melanoma with a BRAF V600 } \\
\text { mutation }\end{array}$ & Melanoma & $228^{\circ}$ & May 2015 \\
\hline MA30130 & Ocrelizumab & $\begin{array}{l}\text { Adult patients with Primary Progressive Multiple Sclerosis (PPMS) (in terms of } \\
\text { disease duration and level of disability) and with imaging features } \\
\text { characteristic of inflammatory activity }\end{array}$ & $\begin{array}{l}\text { Primary } \\
\text { Progressive } \\
\text { Multiple Sclerosis }\end{array}$ & $1,045^{\circ}$ & June 2017 \\
\hline \multirow[t]{2}{*}{ AG40852 } & Entrectinib & $\begin{array}{l}\text { Adult and paediatric patients } 12 \text { years of age and older with solid tumours } \\
\text { expressing a Neurotrophic Tyrosine Receptor Kinase (NTRK) gene fusion, who } \\
\text { have a disease that is locally advanced, metastatic or where surgical resection } \\
\text { is likely to result in severe morbidity, and who have not received a prior NTRK } \\
\text { inhibitor or who have no satisfactory treatment options }\end{array}$ & $\begin{array}{l}\text { Solid tumours } \\
\text { (NTRK) }\end{array}$ & 1 & August 2019 \\
\hline & & $\begin{array}{l}\text { Adult patients with ROS1-positive advanced NSCLC, not previously treated } \\
\text { with ROS1 inhibitors }\end{array}$ & $\begin{array}{l}\text { Non-Small Cell } \\
\text { Lung Cancer }\end{array}$ & $5^{\circ}$ & \\
\hline AG40661 & $\begin{array}{l}\text { Polatuzumab } \\
\text { Vedotin }\end{array}$ & $\begin{array}{l}\text { Adult patients with relapsed/refractory Diffuse Large B-Cell Lymphoma } \\
\text { (DLBCL) who are not candidates for haematopoietic stem cell transplant.lt is } \\
\text { indicated in combination with the treatment of adult patients with benda- } \\
\text { mustine and rituximab }\end{array}$ & $\begin{array}{l}\text { Diffuse Large B- } \\
\text { Cell Lymphoma }\end{array}$ & $151^{\circ}$ & May 2019 \\
\hline AG41381 & Risdiplam & $\begin{array}{l}\text { Patients from } 2 \text { months old with } 5 \text { q spinal muscular atrophy (SMA) Type 1, } \\
\text { Type } 2 \text { or Type } 3 \text {, or those who have up to } 4 \text { copies of SMN2 gene (Type 1) }\end{array}$ & $\begin{array}{l}\text { Spinal Muscular } \\
\text { Atrophy Type } 1\end{array}$ & $28^{\circ}$ & $\begin{array}{l}\text { January } \\
2020\end{array}$ \\
\hline AG42025 & Risdiplam & $\begin{array}{l}\text { Patients from } 2 \text { months old with } 5 \text { q Spinal Muscular Atrophy (SMA) Type 1, } \\
\text { Type } 2 \text { or Type } 3 \text {, or those who have up to } 4 \text { copies of SMN2 gene (Type 2) }\end{array}$ & $\begin{array}{l}\text { Spinal Muscular } \\
\text { Atrophy Type } 2\end{array}$ & 31 & $\begin{array}{l}\text { January } \\
2020\end{array}$ \\
\hline AL41711 & $\begin{array}{l}\text { Trastuzumab } \\
\text { emtansine }\end{array}$ & $\begin{array}{l}\text { Adult patients with HER2-positive, unresectable locally advanced or metastatic } \\
\text { Breast Cancer who previously received trastuzumab and a taxane, separately } \\
\text { or in combination. Patients should have either: (i) received prior therapy for } \\
\text { locally advanced or metastatic disease, or (ii) developed disease recurrence } \\
\text { during or within six months of completing adjuvant therapy. }\end{array}$ & Breast Cancer & $621^{\circ}$ & $\begin{array}{l}\text { September } \\
2019\end{array}$ \\
\hline \multicolumn{4}{|c|}{ Total \# of patients } & \multicolumn{2}{|c|}{$\begin{array}{l}2,745 \\
{ }^{\circ} 2,713 \text { included in } \\
\text { the analysis }\end{array}$} \\
\hline
\end{tabular}

patient treated are higher in our findings. This is mainly caused by the higher cost of the hypothetical SoC used in clinical practice.

It is important that policy makers and healthcare managers appropriately and carefully consider this evidence on the following grounds.

First, the findings represent costs avoided from the perspective of the NHS and not of society as a whole.

Secondly, incremental costs, despite quite negligible, are costs generated by CUP, whereas avoided costs are contingent upon the actual use of alternative treatments.
Thirdly, in this study costs of diagnostic testing and inpatient care have been estimated using the respective fee-for-service/episode, which represents a cost for the NHS, whereas, from the perspective of providers, it represents a revenue.

Based on the above, net savings from compassionate use should not justify delays in decision-making on pricing and reimbursement (P\&R) upon approval of the medicine, on the grounds of shifting the burden from the payer to the industry. In principle, any early access program, like compassionate use, should terminate when 
Table 3 Input data for the economic impact evaluation of CUP

\begin{tabular}{|c|c|c|c|c|c|c|c|}
\hline$\#$ of CUP & Molecule & $\begin{array}{l}\text { Indication } \\
\text { (short) }\end{array}$ & Standard of Care & \multicolumn{2}{|c|}{ Combination medicines } & $\begin{array}{l}\text { Diagnostic } \\
\text { test }\end{array}$ & $\begin{array}{l}\text { Hospitilisations } \\
\text { for side effects* }\end{array}$ \\
\hline MO29499 & Alectinib & $\begin{array}{l}\text { Non-Small Cell } \\
\text { Lung Cancer } 1\end{array}$ & $\begin{array}{l}\text { Ceritinib (1) } \\
\text { Crizotinib (2) }\end{array}$ & \multicolumn{2}{|l|}{-} & $\begin{array}{l}\text { Partially used } \\
\text { with the SoC }\end{array}$ & $0 / 21$ \\
\hline MO40066 & Alectinib & $\begin{array}{l}\text { Non-Small Cell } \\
\text { Lung Cancer } 2\end{array}$ & $\begin{array}{l}\text { Docetaxel (1) } \\
\text { Pemetrexed low dosage (2) } \\
\text { Pemetrexed high dosage (3) } \\
\text { Ceritinib (4) }\end{array}$ & \multicolumn{2}{|l|}{-} & $\begin{array}{l}\text { Used with } \\
\text { the SoC }\end{array}$ & $0 / 226$ \\
\hline ML39740 & Atezolizumab & $\begin{array}{l}\text { Urothelial } \\
\text { Carcinoma }\end{array}$ & $\begin{array}{l}\text { Docetaxel (1) } \\
\text { Nivolumab (2) } \\
\text { Pembrolizumab (3) }\end{array}$ & \multicolumn{2}{|l|}{-} & $\begin{array}{l}\text { Used with } \\
\text { the SoC }\end{array}$ & $7 / 222(3.2 \%)$ \\
\hline AL41528 & Atezolizumab & $\begin{array}{l}\text { Non-Small Cell } \\
\text { Lung Cancer }\end{array}$ & $\begin{array}{l}\text { Pemetrexed low dosage (1) } \\
\text { Pemetrexed high dosage (2) } \\
\text { Bevacizumab+carboplatino+paclitaxel } \\
\text { (3) }\end{array}$ & \multicolumn{2}{|l|}{-} & $\begin{array}{l}\text { Used with } \\
\text { the SoC }\end{array}$ & $1 / 125(0.8 \%)$ \\
\hline AL41712 & Atezolizumab & $\begin{array}{l}\text { Triple-Negative } \\
\text { Breast Cancer }\end{array}$ & Nab-paclitaxel & Nab-paclitaxel & $\begin{array}{l}\text { Covered by } \\
\text { the sponsor }\end{array}$ & $\begin{array}{l}\text { Covered by } \\
\text { the sponsor }\end{array}$ & 2/41 (4.9\%) \\
\hline M029476 & Cobimetinib & Melanoma & $\begin{array}{l}\text { Nivolumab (1) } \\
\text { Vemurafenib (2) } \\
\text { Dabrafenib + trabetinib (3) }\end{array}$ & Vemurafenib & $\begin{array}{l}\text { Not covered } \\
\text { by the } \\
\text { sponsor }\end{array}$ & $\begin{array}{l}\text { Used with } \\
\text { the SoC }\end{array}$ & 14/228 (6.1\%) \\
\hline MA30130 & Ocrelizumab & $\begin{array}{l}\text { Primary } \\
\text { Progressive } \\
\text { Multiple Sclerosis }\end{array}$ & Rituximab & \multicolumn{2}{|l|}{-} & $\begin{array}{l}\text { Not covered } \\
\text { by the } \\
\text { sponsor }\end{array}$ & 13/1,045 (1.2\%) \\
\hline AG40852 & Entrectinib & $\begin{array}{l}\text { Solid tumours } \\
\text { (NTRK) }\end{array}$ & No & \multicolumn{2}{|l|}{-} & $\begin{array}{l}\text { Not covered } \\
\text { by the } \\
\text { sponsor }\end{array}$ & $\begin{array}{l}\text { Not included in } \\
\text { the analysis }\end{array}$ \\
\hline & & $\begin{array}{l}\text { Non-Small Cell } \\
\text { Lung Cancer }\end{array}$ & Crizotinib & \multicolumn{2}{|l|}{-} & $\begin{array}{l}\text { Used with } \\
\text { the SoC }\end{array}$ & $0 / 5$ \\
\hline AG40661 & $\begin{array}{l}\text { Polatuzumab } \\
\text { Vedotin }\end{array}$ & $\begin{array}{l}\text { Diffuse Large B- } \\
\text { Cell Lymphoma }\end{array}$ & $\begin{array}{l}\text { Bendamustine + rituximab (1) } \\
\text { Lenalidomide (648 List) (2) }\end{array}$ & $\begin{array}{l}\text { Bendamustine } \\
\text { + rituximab }\end{array}$ & $\begin{array}{l}\text { Covered by } \\
\text { the sponsor }\end{array}$ & - & 20/151 (13.2\%) \\
\hline AG41381 & Risdiplam & $\begin{array}{l}\text { Spinal Muscular } \\
\text { Atrophy Type } 1\end{array}$ & Nusinersen & \multicolumn{2}{|l|}{-} & - & $0 / 28$ \\
\hline AG42025 & Risdiplam & $\begin{array}{l}\text { Spinal Muscular } \\
\text { Atrophy Type } 2\end{array}$ & No & \multicolumn{2}{|l|}{-} & - & $\begin{array}{l}\text { Not included in } \\
\text { the analysis }\end{array}$ \\
\hline AL41711 & $\begin{array}{l}\text { Trastuzumab } \\
\text { emtansine }\end{array}$ & Breast Cancer & $\begin{array}{l}\text { Trastuzumab + Capecitabina (1) } \\
\text { Lapatinib + } \\
\text { Capecitabina (2) }\end{array}$ & \multicolumn{2}{|l|}{-} & $\begin{array}{l}\text { Not covered } \\
\text { by the } \\
\text { sponsor }\end{array}$ & $0 / 621$ \\
\hline Total & & & 2,713 patients with SoC & \multicolumn{2}{|l|}{ - } & - & $57 / 2,713(2.1 \%)$ \\
\hline
\end{tabular}

* \# of patients / $\%$ of patients recruited

the drug is approved. However, delays in P\&R decisions [65] have resulted in pharmaceutical companies prolonging CUP, to avoid interruptions in the continuity of care of patients. Further, companies should not expect to secure reimbursement and/or a higher price for their medicines on the grounds of the latter's sponsorship of a CUP. As not all medicines used in CUP are necessarily approved for reimbursement in Italy, prices should reflect value [66] and not whether the relevant medicine has been granted early access through CUP.

Our study has some limitations

The first and most important limitation is that we did not estimate the net economic impact of the CUT on disease progression compared to the SoC. This was because CUP are not accompanied by systematic collection of data on effectiveness and resource consumption (apart from diagnostic testing and hospitalisations due to adverse events). Furthermore, had this data been available, they would have required extrapolation beyond the duration of CUP. This extrapolation, besides being out of scope, would have implied a case-control simulation, where for the 'control' arm (SoC or no treatment) data were not available. Another option would have been to adapt published cost-effectiveness analyses on patients treated in CUP through micro-simulation. However the evidence from cost-effectiveness studies is limited, for Italy, only to one study [67].

Secondly, our analysis adopted the perspective of the NHS. To this end, the impact of CUP on other third payers (e.g., social insurance schemes for missed work) and patients and their relatives (e.g., remunerated / informal care provided) was not considered. 
Table 4 Mean averted and incremental cost per patient due to each CUP

\begin{tabular}{|c|c|c|c|c|c|c|c|c|c|c|c|}
\hline \multirow[t]{2}{*}{ \# of CUP } & \multirow[t]{2}{*}{ Molecule } & \multirow[t]{2}{*}{ Indication } & \multicolumn{4}{|c|}{ Mean cost per patient of SoC } & \multirow[t]{2}{*}{ Sources } & \multirow[b]{2}{*}{$\begin{array}{l}\text { Mean } \\
\text { cost } \\
\text { per } \\
\text { patient } \\
\text { of } \\
\text { combi } \\
\text { nation } \\
\text { drugs }\end{array}$} & \multirow{2}{*}{$\begin{array}{l}\text { Mean cost } \\
\text { per } \\
\text { patients } \\
\text { of } \\
\text { diagnostic } \\
\text { test }\end{array}$} & \multirow{2}{*}{$\begin{array}{l}\text { Mean cost } \\
\text { per } \\
\text { (recruited) } \\
\text { patient of } \\
\text { side } \\
\text { effects }\end{array}$} & \multirow[b]{2}{*}{$\begin{array}{l}\text { Mean } \\
\text { cost } \\
\text { per } \\
\text { (hospita } \\
\text { lised) } \\
\text { patient } \\
\text { of side } \\
\text { effects }\end{array}$} \\
\hline & & & SoC1 & SoC2 & SoC3 & SoC4 & & & & & \\
\hline MO29499 & Alectinib & $\begin{array}{l}\text { Non-Small } \\
\text { Cell Lung } \\
\text { Cancer } 1\end{array}$ & $€ 20,350$ & $€ 44,860$ & - & - & $\begin{array}{l}\text { SoC1 [42]; } \\
\text { SoC2 [42, } \\
43]\end{array}$ & - & $€ 106$ & - & - \\
\hline ML40066 & Alectinib & $\begin{array}{l}\text { Non-Small } \\
\text { Cell Lung0 } \\
\text { Cancer } 2\end{array}$ & $€ 2,984$ & $€ 9,700$ & $€ 11,080$ & $€ 14,500$ & $\begin{array}{l}\text { SoC1 [44, } \\
45] \\
\text { SoC2 and } \\
\text { SoC3 [46] } \\
\text { SoC4 [44] }\end{array}$ & - & - & - & - \\
\hline ML39740 & Atezolizumab & $\begin{array}{l}\text { Urothelial } \\
\text { Carcinoma }\end{array}$ & $€ 3,674$ & $€ 12,902$ & $€ 32,223$ & - & $\begin{array}{l}\text { SoC1 [47, } \\
48] \\
\text { SoC2 [49, } \\
50] \\
\text { SoC3 [50, } \\
73]\end{array}$ & - & - & $€ 60$ & $€ 1,922$ \\
\hline AL41528 & Atezolizumab & $\begin{array}{l}\text { Non-Small } \\
\text { Cell Lung } \\
\text { Cancer }\end{array}$ & $€ 9,395$ & $€ 10,732$ & $€ 33,229$ & - & $\begin{array}{l}\text { SoC1 and } \\
\text { SoC2 [46] } \\
\text { SoC3 [51, } \\
52,72]\end{array}$ & - & - & $€ 11$ & $€ 1,404$ \\
\hline AL41712 & Atezolizumab & $\begin{array}{l}\text { Triple- } \\
\text { Negative } \\
\text { Breast } \\
\text { Cancer }\end{array}$ & $€ 7,104$ & - & - & - & $\begin{array}{l}\text { SoC1 }[53, \\
54]\end{array}$ & - & - & $€ 90$ & $€ 1,848$ \\
\hline M029476 & Cobimetinib & Melanoma & $€ 33,824$ & $€ 39,991$ & $€ 41,274$ & - & $\begin{array}{l}\text { SoC1 [55] } \\
\text { SoC2 [55, } \\
56] \\
\text { SoC3 [55] }\end{array}$ & $€ 16,086$ & - & $€ 125$ & $€ 2,029$ \\
\hline MA30130 & Ocrelizumab & $\begin{array}{l}\text { Primary } \\
\text { Progressive } \\
\text { Multiple } \\
\text { Sclerosis }\end{array}$ & $€ 3,002$ & - & - & - & $\begin{array}{l}\text { SoC1 [57, } \\
58]\end{array}$ & - & $€ 20$ & $€ 27$ & $€ 2,139$ \\
\hline AG40852 & Entrectinib & $\begin{array}{l}\text { Non-Small } \\
\text { Cell Lung } \\
\text { Cancer }\end{array}$ & $€ 79,019$ & - & - & - & SoC1 [42] & - & - & - & - \\
\hline AG40661 & $\begin{array}{l}\text { Polatuzumab } \\
\text { Vedotin }\end{array}$ & $\begin{array}{l}\text { Diffuse } \\
\text { Large } \\
\text { B-Cell } \\
\text { Lymphoma }\end{array}$ & $€ 55,583$ & $€ 56,658$ & - & - & $\begin{array}{l}\text { SoC1 }[59, \\
60,69,70,71] \\
\text { SoC2 }[60,61, \\
62]\end{array}$ & - & - & $€ 151$ & $€ 2,488$ \\
\hline AG41381 & Risdiplam & $\begin{array}{l}\text { Spinal } \\
\text { Muscular } \\
\text { Atrophy } \\
\text { Type } 1\end{array}$ & $€ 200,000$ & - & - & - & SoC1 [63] & - & - & - & - \\
\hline AL41711 & $\begin{array}{l}\text { Trastuzumab } \\
\text { emtansine }\end{array}$ & Breast Cancer & $€ 3,780$ & $€ 19,576$ & - & - & $\begin{array}{l}\text { SoC1 and } \\
\text { SoC2 [64] }\end{array}$ & - & $€ 253$ & - & - \\
\hline $\begin{array}{l}\text { Mean cost } \\
\text { for } \\
\text { hospitalised } \\
\text { patients }\end{array}$ & & & & & & & & & & & $€ 2,184$ \\
\hline
\end{tabular}

Indeed, for some diseases, like multiple sclerosis, costs beyond healthcare may play an important role.

Thirdly, since the comparative impact on disease progression and future cost avoidance was not included, we did not conduct an economic impact analysis where no alternative to the CUT was available. The scientific understanding of key molecular pathways and the development of new molecular entities in most of the diseases targeted by the examined CUP present opportunities to fill unmet needs, even in areas with existing alternatives. 
Table 5 Mean and total averted, incremental cost and net costs of CUP

\begin{tabular}{llll}
\hline All programs (2,713 patients) & & & \\
\hline & & Min & Max \\
Averted cost & & & \\
Mean cost per patient of SoC & a & $€ 11,415$ & $€ 20,299$ \\
Total costs of SoC & b & $€ 30,967,593$ & $€ 55,072,260$ \\
Incremental cost & & & \\
Mean cost per patient of CUP & $c$ & $€ 1,646 €$ & \\
Total cost of CUP & $d$ & $€ 4,466,187 €$ & \\
Net cost & & & \\
Net cost per patient & $\mathrm{e}=\mathrm{c}-\mathrm{a} \quad €-9,769 €$ & $€-18,653$ \\
Total net costs & $\mathrm{f}=\mathrm{d}-\mathrm{b} \quad €-26,501,406 €$ & $€-50,606,073$
\end{tabular}

Onco programs (1,640 patients)

\begin{tabular}{llll} 
& & Min & Max \\
Averted cost & & & \\
Mean cost per patient of SoC & $g$ & $€ 13,555 €$ & $€ 28,253$ \\
Total costs of SoC & $h$ & $€ 22,230,423 €$ & $€ 46,335,090$ \\
Incremental cost & & & \\
Mean cost per patient of CUP & i & $€ 2,694$ & \\
Total cost of CUP & $j$ & $€ 4,418,000$ & \\
Net cost & & & \\
Net cost per patient & $k=i-g$ & $€-10,861$ & $€-25,559$ \\
Total net costs & $\mathrm{l}=\mathrm{j}-\mathrm{h}$ & $€-17,812,423$ & $€-41,917,090$ \\
\hline
\end{tabular}

In addition, the absence of long-term follow-up of patients recruited in CUP did not allow for the evaluation of the CUP effects on therapeutic sequencing. It may happen that the SoC is used after the CUP, or vice versa when patients are not recruited in the CUP (i.e., they are first treated with the $\mathrm{SoC}$ and afterwards with the CUT, once it has been approved for reimbursement).

Furthermore, our analysis did not include an estimate of severe adverse events costs for the SoC, normally retrieved from the literature (unless it was used as a comparator in trials for the CUT). This implies an overestimation of the net economic burden of side effects of CUP.

We were also not always able to include the effect of discounts and MEA in the calculation of the cost of the SoC.

The costs of nusinersen for Type-1 Spinal Muscular Atrophy refer to data from the first year of treatment, since real world data on treatment duration beyond the first year were not available.

Incremental costs for diagnostic procedures were estimated on the grounds of the presumed clinical practice with the $\mathrm{SoC}$ and assuming maximum impact for the
NHS. For example, we decided to include (i) IHC to detect ALK-positive patients, despite its use with crizotinib as an alternative to alectinib for adult patients with advanced NSCLC and (ii) FISH for trastuzumab emtansine, despite its use with trastuzumab as a neo-adjuvant therapy. If the cost of these two diagnostic procedures were eliminated, the calculated incremental cost would decrease from $€ 4.5$ million to $€ 4.3$ million with a net economic benefit ranging from $€ 26.7$ million (instead of $€ 26.5)$ to $€ 50.8$ million (instead of $€ 50.6$ million).

Finally, while different SoC were identified, we did not have any information on their use in clinical practice. This information could have allowed for the calculation of a weighted mean cost per patient receiving the respective SoC. Thus, we were only able to provide a minimum and maximum average averted cost per patient, where the actual mean cost depends on the present market share of each single SoC.

Despite these limitations, this paper constitutes the first evidence on the economic advantages of medicines provided for compassionate use.

\section{Conclusions}

CUP have been introduced to guarantee earlier access to medicines for patients not recruited in trials, responding to the ethical imperative of addressing unmet needs. In this paper, we have demonstrated that CUP have important advantages also from an economic standpoint. Beyond their economic impact, they can serve as an important source of data, enhancing information availability during the approval and $P \& R$ processes. This, however, would imply more systematic data collection on clinical outcomes and on the impact from the perspective of patients, as well as on health resources. Such data collection would also inform a more comprehensive economic evaluation of these programs.

In conclusion, CUP for medicines represent an opportunity to accelerate patient access to medicines for rare and severe diseases, in cases where patients have not been recruited or are not eligible for recruitment in clinical trials. For clinicians who have not been involved in clinical trials, they represent an opportunity to familiarise with medicines likely to become available in clinical practice. For health care payers they present cost saving opportunities, while the impact and savings could be larger if the societal perspective is considered.

\section{Abbreviations}

ALK: Anaplastic Lymphoma Kinase; CT: Clinical Trial(s)

CUP: Compassionate Use Program(s); CUT: Compassionate Use Treatment(s); DCA: Drug Cost Avoidance; FISH: Fluorescent In Situ Hybridization;

DLBCL: Diffuse Large B-Cell Lymphoma; DRG: Diagnosis-Related Group; IHC: Immuno-Histo-Chemistry; MEA: Managed Entry Agreements;

MedDRA: Medical Dictionary for Regulatory Activities; NSCLC: Non-Small Cell Lung Cancer; NTRK: Neurotrophic Tyrosine Receptor Kinase; PCA: Pathology Cost Avoidance; P\&R: Pricing \& Reimbursement; PPMS: Primary Progressive 
Multiple Sclerosis; SMA: Spinal Muscular Atrophy; SmpC: Summary of Product Characteristics; SoC: Standard of Care; TNBC: Triple-Negative Breast Cancer; UC: Urothelial Carcinoma

\section{Supplementary information}

The online version contains supplementary material available at https://doi. org/10.1186/s12913-021-07255-w.

\section{Additional file 1}

\section{Acknowledgements}

The authors would like to acknowledge (i) Letizia Fusco and Lorella Colombi of Roche Italy for the collection of the internal data, including pharmacovigilance data, on the 11 CUP analysed in this study; (ii) Helen Banks of CERGAS, SDA Bocconi, for her revision of English text.

\section{Authors' contributions}

CJ co-designed the work, contributed to the analysis and data interpretation, and drafted the paper with the exception of the Literature Search analysis. FP and LS worked on data extraction, contributed to interpretation of data and revised the paper. MC co-designed the work, contributed to the analysis and data interpretation and revised the paper. MV carried out the literature search, co-drafted the 'Background section' and drafted the Literature Search analysis of the paper, contributed to data interpretation and revised the paper. All authors have approved the submitted version and have agreed both to be personally accountable for the author's own contributions and to ensure that questions related to the accuracy or integrity of any part of the work, even ones in which the author was not personally involved, are appropriately investigated, resolved, and the resolution documented in the literature.

\section{Funding}

This research was conducted thanks to an unconditional grant from Roche Italy to Cergas, Centre for Research on Health and Social Care Management. Roche provided Cergas with the CUP Dataset and co-authored the paper.

\section{Availability of data and materials}

The datasets used and/or analysed during the current study are available from the corresponding author on reasonable request.

\section{Declarations}

\section{Ethics approval and consent to participate}

This study does not require ethics approval and consent to participate.

\section{Consent for publication}

Consent for publication is not needed.

\section{Competing interests}

CJ received research grants from Abbvie, Alnylam, Amgen, Astrazeneca, Bayer, BMS, Boehringer I, Celgene, EuroQoL Foundation, FSK, Gilead, Janssen C, MSD, Novartis, Roche, Pfizer, Sandoz, Sanofi, Takeda, Teva for his research activity and acted as a speaker and or consultant for Amgen, Astrazeneca, BMS, Celgene, CSL Behring, Dephaforum, Gilead, Incyte, MA Provider, MSD, Roche, Sanofi, Takeda, Wellmera (now Alira Health). FP and LS are employed by Roche Italy. MC received research grants from Amgen, Novartis and Roche for her research activity. MV declares no competing interests.

\section{Author details}

${ }^{1}$ Centre for Research on Health and Social Care Management, SDA Bocconi School of Management, CERGAS, Bocconi University, Via Sarfatti 25, 20136 Milano, MI, Italy. ${ }^{2}$ ROCHE Spa, Viale GB Stucchi 110, MB 20900 Monza, Italy.

Received: 2 July 2021 Accepted: 27 October 2021

Published online: 04 December 2021

\section{References}

1. Watson TA. Global Perspective on Compassionate Use and Expanded Access. Ther Innov Regul Sci. 2017;51:143-5.
2. European Parliament. $32004 R 0726$ Regulation (EC) No 726/2004 of the European Parliament and of the Council of 31 March 2004 laying down Community procedures for the authorisation and supervision of medicinal products for human and veterinary use and establishing a European Medicines Agency. Official Journal L136. 2004;1-33. http://data.europa.eu/ eli/reg/2004/726/oj. Accessed 15 Mar 2021.

3. European Medicines Agency. Guideline on Compassionate Use of Medicinal Products, Pursuant to Article 83 of Regulation (Ec) No 726/2004. European Medicines Agency. London, UK, 2007;1-8. https://www.ema.europa.eu/en/ human-regulatory/research-development/compassionate-use. Accessed 15 Mar 2021.

4. Balasubramanian G, Morampudi S, Chhabra P, Gowda A, Zomorodi B. An overview of Compassionate Use Programs in the European Union member states. Intractable Rare Dis Res. 2016;5(4):244-254.

5. Ministero della Salute. DECRETO 7 settembre 2017 Disciplina dell'uso terapeutico di medicinale sottoposto a sperimentazione clinica (17A07305) (GU Serie Generale n.256 del 02-11-2017). https://www.gazzettaufficiale.it/ eli/id/2017/11/02/17A07305/SG. Accessed 15 Mar 2021.

6. Polak T, Uyl-de Groot CA, Van Rosmalen J. PNS410 Data from expanded access programs: treatment first, collection second. An overview of FDA and EMA regulatory approvals. Value in Health. 2019;22 Suppl 3:835.

7. Bunnik, EM, Aarts, N. What do patients with unmet medical needs want? A qualitative study of patients' views and experiences with expanded access to unapproved, investigational treatments in the Netherlands. BMC Medical Ethics. 2019;20:80.

8. Bunnik, EM, Aarts, N. The Role of Physicians in Expanded Access to Investigational Drugs: A Mixed-Methods Study of Physicians' Views and Experiences in The Netherlands. Bioethical Inquiry. 2021;18:319-334.

9. Caplan AL, Teagarden JR, Kearns L, Bateman-House AS, Mitchell E, Arawi T, et al. Fair, just and compassionate: A pilot for making allocation decisions for patients requesting experimental drugs outside of clinical trials. J Med Ethics. 2018;44(11):761-767.

10. Armeni P, Bertolani A, Borsoi L, Costa F. La spesa sanitaria: composizione ed evoluzione. In Cergas Bocconi (ed.). Rapporto Oasi 2020. Egea, Milano. https://www.cergas.unibocconi.eu/observatories/oasi_/oasi-report-2020. Accessed 14 Oct 2021.

11. Jommi C, Minghetti P. Pharmaceutical Pricing Policies in Italy, in Zaheer-UdDin Babar editor, Pharmaceutical Prices in the 21st Century. London: Springer; 2015. p. 131-51.

12. Medicines Utilisation Monitoring Centre. National Report on Medicines use in Italy. Year 2020. Rome: Italian Medicines Agency; 2021. https://www.aifa. gov.it/uso-dei-farmaci-in-italia. Accessed 14 Oct 2021

13. Harrison J, Mozzicato P. MedDRA ${ }^{\oplus}$ : The tale of a terminology: Side Effects of Drugs Essay. Side Eff Drugs Annu. 31 2009. doi:https://doi.org/10.1016/S03 78-6080(09)03160-2.

14. OSFAR - Osservatorio Farmaci. Report n. 38- Report Annuale per il 2017. CERGAS - Universita' Bocconi. 2018. https:/www.cergas.unibocconi.eu/sites/ default/files/files/Report38.pdf. Accessed 15 Mar 2021.

15. Tikkanen R, Wharton G, Djordjevic A, Mossialos E, Williams II RD. The 2020 International Profiles of Healthcare Systems: A Useful Resource for Interpreting Country Responses to the COVID-19 Pandemic. https://www.commonwealthfund.org/blog/2020/2020-internationalprofiles-useful-resource-interpreting-responses-covid-19. Accessed 15 Mar 2021.

16. Regione Lombardia, Prestazioni ambulatoriali - Open Data. 2021. https:// www.dati.lombardia.it/Sanit-/Prestazioni-Ambulatoriali/d4mg-9zw3. Accessed 1 Dec 2020

17. Regione Veneto, Nomenclatore Tariffario Regionale Assistenza Specialistica Ambulatoriale, Allegato B del Decreto di Giunta Regionale n. 47 del 22 Maggio 2013. https://www.regione.veneto.it/web/sanita/assistenza-ambula toriale\#\%22Nomenclatore_tariffario\%22. Accessed 1 Dec 2020.

18. Decreto del Presidente del Consiglio dei Ministri 12 gennaio 2017. Definizione e aggiornamento dei livelli essenziali di assistenza, di cui all'articolo 1, comma 7, del decreto legislativo 30 dicembre 1992, n. 502. (17A02015) (GU Serie Generale n.65 del 18-03-2017 - Suppl. Ordinario n. 15). https:/www.gazzettaufficiale.it/eli/id/2017/03/18/17A02015/sg. Accessed 15 Mar 2021

19. Tariffari nazionali delle prestazioni del Ssn https:/www.salute.gov.it/portale/ temi/p2_6.jsp?id=3662\&area=programmazioneSanitariaLea\&menu=vuoto. Accessed 15 Mar 2021

20. Calcolo DRG. http://www.e-drg.it/. Accessed 15 Feb 2021. 
21. LaFleur J, Tyler LS, Sharma RR. Economic benefits of investigational drug services at an academic institution. Am J Health-Syst Pharm. 2004;61(1):27-32.

22. McDonagh MS, Miller SA, Naden E, et al. Costs and savings of investigational drug services. Am J Health-Syst Pharm. 2000;57(1):40-43.

23. Uecke O, Reszka R, Linke J, Steul M, Posselt T. Clinical trials: considerations for researchers and hospital administrators. Healthcare Manage Rev. 2008; 33(2):103-12.

24. Truong K, Kwan YL, Nigro L, Huseincehajic A, Trotman J, et al. Retrospective pharmaceutical financial benefits and cost avoidance analysis of clinical trial participation in the Australian haematology setting. Intern Med J. 2019;49(9): 1092-1098.

25. Walter E, Eichhober G, Voit M, Baumgartner C, Celedin A, et al. Economic impact of industry sponsored clinical trials of pharmaceutical products in Austria, J Med Econ 2020;23(6):566-574.

26. Tang PA, Hay AE, O'Callaghan CJ, Mittmann N, Chambers CR, et al. Estimation of drug cost avoidance and pathology cost avoidance through participation in NCIC Clinical Trials Group phase III clinical trials in Canada. Curr Oncol. 2016;23 Suppl 1:7-13.

27. Bredin C, Eliasziw M, Syme R. Drug cost avoidance resulting from cancer clinical trials. Contemp Clin Trials. 2010;31:524-529.

28. Jones B, Eliasziw M, Eigl BJ, Syme R, et al. A comparison of incremental costs of breast cancer clinical trials to standard of care. J Clin Trials. 2015;5:216.

29. Herledan C, Ranchon F, Schwiertz V, Baudouin A, Karlin L, et al. Drug cost savings in phase III hematological oncology clinical trials in a university hospital. Hematol Oncol. 2020;38:576-583.

30. Grossi F, Genova C, Gaitan ND, Dal Bello MG, Rijavec E, et al. Free drugs in clinical trials and their potential cost saving impact on the National Health Service: a retrospective cost analysis in Italy. Lung Cancer. 2013; 81:236-240.

31. D'Ambrosio F, De Feo G, Botti G, Capasso A, Pignata S, et al. Clinical trials and drug cost savings for Italian health service. BMC Health Serv Res. 2020; 20:1089.

32. Cicchetti A, Addesso D, Leone FE, Amato A, Angerame L, et al. Valorization of clinical trials from the Italian National Health Service perspective: definition and first application of a model to estimate avoided costs. Glob Reg Health Technol Assess. 2020;7(1):26-32.

33. Calvin-Lamas M, Portela-Pereira P, Rabuñal-Alvarez MT, Martinez-Breijo S, Martín-Herranz MI, Gómez-Veiga F. Drug cost avoidance in prostate cancer clinical trials. Actas Urol Esp. 2015;39:553-557.

34. Alamo AM, Mateos E, Nucete B, Lujan ME, Lombardero M, Otero C. 4CPS-107 An estimate of avoided costs for drugs in patients included in non-small lung cancer clinical trials. Eur J Hosp Pharm. 2018;25 Suppl 1:A91-A92.

35. Mañes-Sevilla M, Romero-Jiménez R, Herranz-Alonso A, Sánchez-Fresneda M, Gonzalez-Haba E, et al. Drug cost avoidance in clinical trials of breast cancer. J Oncol Pharm Pract. 2019;25(5):1099-1104.

36. Henares López A, Del Río Valencia JC, Tamayo Bermejo R, Rosado Souviron MA, Muñoz Castillo I. Avoided cost study of drugs in clinical trials at a tertiary hospital. Hospital Regional Universitario de Málaga, Hospital Pharmacy, Málaga, Spain. 2020. https://ejhp.bmj.com/content/ejhpharm/26/ Suppl_1/A4.2.full.pdf. Accessed 15 Mar 2021

37. Shen $L$, Chou H, Huang CF, Chou GM, Chan WK, Wu FL. Economic benefits of sponsored clinical trials on pharmaceutical expenditures at a medical center in Taiwan. Contemp Clin Trials. 2011;32:485-491.

38. Koçkaya G, Demir M, Kockaya PD, Tatar M, Üresin AY. Economic Impact of Clinical Research to Research Centers and Opportunity Cost for the Reimbursement System in Turkey. Health 2015;7:1124-1133.

39. Liniker E, Harrison M, Weaver JM, Agrawal N, Chhabra A, et al. Treatment costs associated with interventional cancer clinical trials conducted at a single UK institution over 2 years (2009-2010). Br J Cancer. 2013;109:2051-2057.

40. Battelle Technology Partnership Practice. Biopharmaceutical IndustrySponsored Clinical Trials: Impact on State Economies. Ohio; 2015. http:// phrma-docs.phrma.org/sites/default/files/pdf/biopharmaceutical-industrysponsored-clinical-trials-impact-on-state-economies.pdf. Accessed 15 Mar 2021.

41. Mladsi D, Hess LM, Barnett CL, Njue A, Huang YJ, et al. Value of clinical trial narrative data to estimate the costs of adverse event management: a feasibility study, J Med Econ. 2020;23(3):213-220.

42. Regione Veneto - Gruppo Farmaci Innovativi del Coordinamento della Rete Oncologica Veneta (ed.), Raccomandazione n. 31 Carcinoma polmonare non a piccole cellule per la chinasi del linfoma anaplastico (ALK+) I linea. July 2020. Annex A of Regional Decree no. 80/2020. https://www.regione. veneto.it/documents/10793/1016153/Decreto+del+Direttore+Generale+A
rea+Sanit\%C3 \%A0+e+Sociale+n.+80+del+04.08.2020.pdf/4df293b2-d41d4b95-9c18-00c4a3594b18. Accessed 15 Mar 2021.

43. Peters S, Camidge R, Shaw AT, Gadgeel S, Ahn, JS, et al. Alectinib versus Crizotinib in Untreated ALK-Positive Non-Small-Cell Lung Cancer. N Engl J Med. 2017;377:829-38.

44. Regione Veneto - Gruppo Farmaci Innovativi del Coordinamento della Rete Oncologica Veneta. Raccomandazione n. 32 Carcinoma polmonare non a piccole cellule per la chinasi del linfoma anaplastico (ALK+) II linea. July 2020. Annex A of Regional Decree no. 81/2020. https://www.regione.veneto. it/documents/10793/1016153/Decreto+del+Direttore+Generale+Area+Sa nit\%C3 \%A0+e+Sociale+n.+81+del+04.08.2020.pdf/d5ef89ee-2a13-4f76-86ef8a796b852e04. Accessed 15 Mar 2021.

45. Novello S, Mazières J, Oh I-J, de Castro J, Migliorino MR, Helland $\AA$, et al. Alectinib versus chemotherapy in crizotinib-pretreated anaplastic lymphoma kinase (ALK)-positive non-small-cell lung cancer: results from the phase III ALUR study. Ann Oncol. 2018;29(6):1409-16.

46. Regione Veneto - Gruppo Farmaci Innovativi del Coordinamento della Rete Oncologica Veneta. Raccomandazione n. 13 Pemetrexed - Alimta ${ }^{\circledR}$, Allegato C al Decreto n. 253 del 28 agosto 2015. https://salute.regione.veneto.it/c/ document_library/get_file?uuid=8d73e93f-d9d2-4c4a-a67d-2d3c2 80df78d\&groupld=534936. Accessed 15 Mar 2021.

47. AIFA. Regime di rimborsabilita' e prezzo di vendita del medicinale «Docetaxel Teva» (docetaxel) autorizzata con procedura centralizzata europea. Determinazione 18th November 2010 (10A14171) GU Serie Generale n.283 del 03-12-2010. https://www.gazzettaufficiale.it/eli/id/201 0/12/03/10A14171/sg. Accessed 15 Mar 2021.

48. Powles T, Durán I, van der Heijden MS, Loriot Y, Vogelzang NJ, et al. Atezolizumab versus chemotherapy in patients with platinum-treated locally advanced or metastatic urothelial carcinoma (IMvigor211): a multicentre, open-label, phase 3 randomised controlled trial. Lancet 2018;391:748-57.

49. AIFA, Regime di rimborsabilità e prezzo del medicinale «Opdivo». Determina no. 1403/2018. GU Serie Generale n. 224 del 26.09.18. https:/uww.medicoeleggi.com/a rgomenti000/italia2018/410465.html. Accessed 15 Mar 2021.

50. Regione Toscana - Commissione Terapeutica Regionale Atezolizumab (TECE NTRIQ ${ }^{\text {TM}}$ ). 1 ottobre 2018. https://www.regione.toscana.it/documents/101 80/15552024/SchedaTecentriq-atezolizumab.pdf/7dfe2062-4eb7-4bceb065-107d2a27b664. Accessed 15 Mar 2021.

51. AIFA. Determina 15 settembre 2020 Rinegoziazione del medicinale per uso umano «Avastin» ai sensidell'articolo 8, comma 10, della legge 24 dicembre 1993, n. 537. (Determina n. DG/934/2020). (20A05115) (GU n.238 del 25-92020). https://www.aifa.gov.it/documents/20142/961234/Determina-DG934-2020_Avastin.pdf.

52. Russo A, Priolo D, Antonelli G, Libra M, McCubrey JA, Ferrau F. Bevacizumab in the treatment of NSCLC: patient selection and perspectives. Lung Cancer (Auckl). 2017;8:259-269.

53. AIFA. Regime di rimborsabilita' e prezzo a seguito di nuove indicazioni terapeutiche del medicinale per uso umano «Abraxane» (paclitaxelalbumina). Determina no. 57/2015 (15A00779). GU Gazzetta Ufficiale Serie Generale n.30 del 06-02-2015 https://www.gazzettaufficiale.it/atto/serie_ generale/caricaDettaglioAtto/originario?atto.dataPubblicazioneGazzetta=201 5-02-06\&atto.codiceRedazionale=15A00779\&elenco30giorni=false. Accessed 15 Mar 2021.

54. Caparica R, Lambertini M, de Azambuja E. How I treat metastatic triplenegative breast cancer. ESMO Open. 2019;4:e504.

55. Regione Veneto - Gruppo Farmaci Innovativi del Coordinamento della Rete Oncologica Veneta. Raccomandazione n. 25 Anticorpi ANTI-PD-1 e BRAF inibitore/MEK inibitore - melanoma inoperabile o metastatico (Decreto n. 91 del 25 luglio 2017). https://www.regione.veneto.it/web/sanita/raccomanda zioni-farmaci-oncologici. Accessed 15 Mar 2021.

56. AIFA. Regime di rimborsabilita' e prezzo di vendita del medicinale per uso umano «Zelboraf (vemurafenib)», autorizzata con procedura centralizzata europea dalla Commissione europea. Determina n. 500/2013 (13A04712). GU Serie Generale n.129 del 04-06-2013 https://www.gazzettaufficiale.it/eli/ id/2013/06/04/13A04712/sg. Accessed 15 Mar 2021.

57. Regione Toscana - Commissione Terapeutica Regionale. Ocrelizumab (Ocrevus). 5th November 2018. https://www.regione.toscana.it/documents/1 0180/15552024/Scheda+Ocrevus-Ocrelizumab.pdf/04e2a03f-b8d7-4573-803 e-199a2704a13f. Accessed 15 Mar 2021.

58. Hauser SL, Waubant E, Arnold DL, Vollmer T, Antel J, et al. B-Cell Depletion with Rituximab in Relapsing-Remitting Multiple Sclerosis. N Engl J Med. 2008;358:676-88. 
59. AIFA. Inserimento del medicinale Bendamustina nell'elenco dei medicinali erogabili a totale carico del Servizio sanitario nazionale ai sensi della legge 23 dicembre 1996, n. 648, per il trattamento del linfoma diffuso a grandi cellule $B$ primitivo o trasformato da forme a basso grado, recidivato/refrattario ( $\geq 2$ linee di terapia), in combinazione con rituximab con o senza citarabina. Determina n. 3390/2020). (20A00467), GU Serie Generale n.20 del 25-01-2020. https://www.ga zzettaufficiale.it/atto/serie_generale/caricaDettaglioAtto/originario?atto.da taPubblicazioneGazzetta=2020-01-25\&atto.codiceRedazionale= 20A00467\&elenco30giorni=false. Accessed 15 Mar 2021.

60. Sehn LH, Herrera AF, Flowers CR, Kamdar MK, McMillan A, et al. Polatuzumab Vedotin in Relapsed or Refractory Diffuse Large B-Cell Lymphoma. J Clin Oncol. 2019;38:155-165.

61. AlFA. Regime di rimborsabilita' e prezzo, a seguito di nuove indicazioni terapeutiche, del medicinale per uso umano «Revlimid». Determina no 753/ 2018 (18A03533), https://www.aifa.gov.ti/documents/20142/241028/ Determina_753-2018_Revlimid.pdf/c054c839-c9a9-a7f5-05b6-698fe7be6a9e. Accessed 15 Mar 2021

62. Czuczman MS, Trněný M, Davies A, Rule S, Linton KM, et al. A Phase 2/3 Multicenter, Randomized, Open-Label Study to Compare the Efficacy and Safety of Lenalidomide Versus Investigator's Choice in Patients with Relapsed or Refractory Diffuse Large B-Cell Lymphoma. Clin Cancer Res. 2017;23(15):4127-4137.

63. Magnano R. Sma, così una terapia innovativa diventa «buona sanità». Sanita' 24. 2018. https://www.sanita24.ilsole24ore.com/art/dal-governo/2018-03-14/ sma-cosi-terapia-innovativa-diventa-buona-sanita-124808.php?uuid= AE88jIGE. Accessed 15 Mar 2021.

64. Regione Veneto - Gruppo Farmaci Innovativi del Coordinamento della Rete Oncologica Veneta. Raccomandazione n. 2 Trastuzumab Emtansine Kadcyla ${ }^{\oplus}$, Annex B of Regional Decree no. 119/2015. https://www.regione. veneto.it/c/document_library/get_file?uuid=e687fa0b-4080-4cef-b101-04 77c2190f93\&groupld=10793. Accessed 15 Mar 2021.

65. IQVIA. EFPIA Patients W.A.I.T. Indicator 2019 Survey May 2020. 2020. https:// www.efpia.eu/publications/downloads/efpia/efpia-patients-wait-indicator-2 019-survey/. Accessed 15 Mar 2021.

66. Jommi C, Armeni P, Costa F, Bertolani A, Otto M. Implementation of Valuebased Pricing for Medicines. Clin Ther. 2020:42(1):15-24.

67. Ravasio R, Tiseo M, Pradelli L, Bellone M, Gervasi A, Coffani M. Costeffectiveness analysis of alectinib versus crizotinib in first-line treatment of anaplastic lymphoma kinase-positive advanced non-small cell lung cancer, Glob Reg Health Technol Assess. 2019:1-11.

68. AIFA, Farmaci ad uso compassionevole. https://www.aifa.gov.it/farmaci-auso-compassionevole. Accessed 14 Oct 2021.

69. AlFA. Riclassificazione del medicinale per uso umano «Bendamustina Accord» ai sensi dell'articolo 8, comma 10, della legge 24 dicembre 1993, n. 537. Determina no. 730/2016 (16A04416), GU Serie Generale n.137 del 1406-2016. https:/www.gazzettaufficiale.it/eli/id/2016/06/14/16A04416/sg. Accessed 15 Mar 2021.

70. Hong JY, Yoon DH, Suh C, Kim WS, Kim SJ, et al. Bendamustine plus rituximab for relapsed or refractory diffuse large B cell lymphoma: a multicenter retrospective analysis. Ann Hematol. 2018;97:1437-1443.

71. Salles G, Barrett M, Foà R, Maurer J, O'Brien S, et al. Rituximab in B-Cell Hematologic Malignancies: A Review of 20 Years of Clinical Experience. Adv Ther. 2017;34:2232-2273.

72. Roche Registration GmbH. Annex I - Summary Product Characteristics. In: European Medicines Agency. Avastin: EPAR - Product Information (20/01/ 2021 Avastin - EMEA/H/C/000582 - IB/0119). https://www.ema.europa.eu/ en/documents/product-information/avastin-epar-product-information_en. pdf. Accessed 15 Mar 2021

73. AIFA. Regime di rimborsabilita' e prezzo a seguito di nuove indicazioni terapeutiche del medicinale per uso umano «Keytruda». Determina no. 1764/2019. (19A07665). GU Serie Generale n.290 del 11-12-2019. https:// www.aifa.gov.it/documents/20142/961234/Determina_1764-2019_ Keytruda_ca.uroteliale.pdf/29fdd26e-28aa-24b8-84e7-fa3539397d38. Accessed 15 Mar 2021.

\section{Publisher's Note}

Springer Nature remains neutral with regard to jurisdictional claims in published maps and institutional affiliations.

\section{Ready to submit your research? Choose BMC and benefit from}

- fast, convenient online submission

- thorough peer review by experienced researchers in your field

- rapid publication on acceptance

- support for research data, including large and complex data types

- gold Open Access which fosters wider collaboration and increased citations

- maximum visibility for your research: over $100 \mathrm{M}$ website views per year

At $\mathrm{BMC}$, research is always in progress.

Learn more biomedcentral.com/submissions 